\title{
NOTE
}

\section{Hyperthermia reduces viral load of white spot syndrome virus in Penaeus vannamei}

\author{
Clarissa B. Granja*, Oscar M. Vidal, Gustavo Parra, Marcela Salazar
}

Corporación Centro de Investigación de la Acuicultura de Colombia (CENIACUA), Carrera 8a \# 96-60, Bogotá, Colombia

\begin{abstract}
We have previously reported that white spot syndrome virus-infected Penaeus vannamei (also called Litopenaeus vannamei) maintained at $32^{\circ} \mathrm{C}$ show higher survival rates and a significant increase in number of apoptotic cells when compared to infected shrimp kept at $26^{\circ} \mathrm{C}$. As apoptosis plays an important part in the antiviral response of invertebrates, we hypothesized that this process would reduce WSSV replication, allowing the shrimp to control the disease and survive. To test this hypothesis, shrimp were orally infected and maintained at either $26^{\circ} \mathrm{C}$ (Group 1 ) or $32^{\circ} \mathrm{C}$ (Group 2), DNA was extracted from haemolymph collected at various times from 6 to $216 \mathrm{~h}$ postinfection, and the number of viral units was quantified by real time PCR using SYBR Green. In parallel, histological examination was carried out to confirm the WSSV infection and to rule out concomitant diseases. Linear regression of real time PCR units (rtPCRU) of WSSV from Group 1 showed a significant increase with time post-infection $\left(\mathrm{r}^{2}=0.7383 ; \mathrm{p}<0.001\right)$. Conversely, there was no increase in rtPCRU with time post-infection in Group $2\left(\mathrm{r}^{2}=0.142\right)$, indicating that hyperthermia inhibited, either directly or indirectly, viral replication. In addition, comparison between the groups showed no difference in WSSV rtPCRU up to $48 \mathrm{~h}$ post-infection. After $72 \mathrm{~h}$, shrimp from Group 1 had a significantly higher viral rtPCRU (ANOVA, $p<0.001$ ). We conclude that hyperthermia-associated WSSV rtPCRU reduction could reflect either an increase in the shrimp antiviral response, or a direct negative effect on viral replication, or both.
\end{abstract}

KEY WORDS: White spot syndrome virus · Real time PCR units · Viral load $\cdot$ Hyperthermia $\cdot$ Penaeus vannamei

Resale or republication not permitted without written consent of the publisher

\section{INTRODUCTION}

White spot syndrome virus (WSSV) was first reported in 1992 in East Asia, and during the last decade it has spread to nearly all shrimp-farming areas (Huang et al. 1994, Inouye et al. 1994). It has become one of the most harmful viral pathogens to the worldwide shrimp industry (Rosenberry 2002). Diagnosis is based on clinical signs and laboratory tests, including histological analysis (Lightner 1996), Western blot and immunohistochemistry with monoclonal antibodies (Nadala et al. 1997, Magbanua et al. 2000, Nadala \& Loh 2000, Poulos et al. 2001, Anil et al. 2002), dot-blot and in situ hybridization using gene probes (Durand et al. 1996, Nunan \& Lightner 1997), polymerase chain reaction (PCR) (Wang et al. 1995, Lo et al. 1996) and real time
PCR (Durand \& Lightner 2002). In most cases, the clinical signs such as lethargy, reduction in food consumption and reddish coloration are not pathognomonic (Lightner 1996). In addition, the typical white spots that develop in the exoskeleton are not often seen in Penaeus vannamei. Therefore, laboratory tests are required for definitive diagnosis. Real time PCR is a useful quantification method that enables the determination of viral units in infected shrimp tissues, which we know to be one of the most important factors in progression and transmission of the disease (Durand \& Lightner 2002).

WSSV is a large double-stranded, enveloped DNA virus of the genus Whispovirus, family Nimaviridae (Vlak et al. 2004). The complete genome sequence has been published (van Hulten et al. 2001, Yang et al. 2001), and more recently many WSSV proteins have 
been characterized using functional genomics and proteomics (Tsai et al. 2004).

By examining environmental effects on WSSV infection in Penaeus vannamei we found that hyperthermia drastically reduced the mortality rates (Vidal et al. 2001). This prompted us to investigate whether apoptosis played a role in the effect. By analyzing the number of apoptotic cells in shrimp maintained at ambient temperature $\left(25^{\circ} \mathrm{C}\right)$ and in heated tanks $\left(32^{\circ} \mathrm{C}\right)$, we showed that shrimp kept at $32^{\circ} \mathrm{C}$ had a significantly higher number of apoptotic cells (Granja et al. 2003). These results suggest that apoptosis had reduced viral replication, allowing the shrimp to control the disease and survive.

To determine the effect of hyperthermia on real time PCR units (rtPCRU) in our WSSV experimental model, we quantified viral infection by real time PCR using a fluorescent dye, SYBR Green (Dhar et al. 2001). The results demonstrated a reduction of rtPCRU in shrimp maintained at $32^{\circ} \mathrm{C}$ compared with $26^{\circ} \mathrm{C}$, prompting us to question whether this effect was due to a temperature-associated modulatory effect on the shrimp antiviral response, or on the viral replication process per se, or both.

\section{MATERIALS AND METHODS}

Animals and experimental conditions. Penaeus vannamei of $4 \mathrm{~g}$ average weight used in these experiments were bred in captivity at CENIACUA's facilities located in Cartagena, Colombia. Before the trials, shrimp were acclimated for $10 \mathrm{~d}$ at the CENIACUA Bioassay Laboratory in Bogota. To exclude the presence of WSSV prior to experimental infection, pleopods from 30 shrimp in the same batch (full siblings) were tested by nested PCR (Lo et al. 1996).

Inoculum preparation. Viral inoculum was prepared as described previously (Vidal et al. 2001). In brief, muscle tissue and cuticle from WSSV-infected shrimp were gathered, pooled and homogenized in $0.9 \% \mathrm{NaCl}$. Tissue homogenate was centrifuged and filtered through a $0.2 \mu \mathrm{m}$ membrane filter. WSSV rtPCRU in the cell- and bacteria-free extract was quantified using real time PCR protocol as described below. After quantification, the extract was aliquoted in $2 \mathrm{ml}$ vials and stored at $-70^{\circ} \mathrm{C}$.

Experimental conditions. Shrimp were maintained in 20001 plastic tanks containing chlorinated, filtered seawater, 35 ppt salinity, under constant aeration with zero water exchange. The 2 water temperatures used were $26 \pm 0.5^{\circ} \mathrm{C}$ (ambient temperature, hereafter referred to as $26^{\circ} \mathrm{C}$ ) and $31.6 \pm 2{ }^{\circ} \mathrm{C}$ (hereafter referred to as $32^{\circ} \mathrm{C}$ ) maintained by immersion heaters (Aquarium system VISI Therms Vtn 100, VISI Therm Technology). The shrimp were fed twice daily with a commercial diet (Nicovita $35 \%$ protein).
Experimental design. As described in Vidal et al. (2001), shrimp were individually infected with WSSV by placing $20 \mu$ l of the inoculum (which contained $7.5 \times 10^{3}$ rtPCRU of WSSV) into the oral cavity using a $28 \mathrm{G}$ venocath catheter (Becton Dickinson ${ }^{\circledR}$ ) connected to a repeater pipette (Eppendorf). Two experimental groups of WSSV-free Penaeus vannamei were infected and kept at either $26^{\circ} \mathrm{C}$ (Group 1) or $32^{\circ} \mathrm{C}$ (Group 2). Samples from 5 uninfected shrimp were used as negative controls.

Haemolymph was collected from 5 shrimp in Group 2 at $6,18,24,48,72,96,120,144,168,192$ and 216 h postinfection $(\mathrm{n}=55)$. Group 1 was analyzed up to $192 \mathrm{~h}$ post-infection $(n=50)$, after which there were no survivors. Each haemolymph sample of $100 \mu$ l was taken with a $1 \mathrm{ml}$ syringe containing $5 \mu \mathrm{M}$ EDTA. After haemolymph collection, shrimp were sacrificed and fixed in Davidson's fixative for $24 \mathrm{~h}$ and then transferred to $70 \%$ ethanol until processing, as described previously for routine histopathology (Bell \& Lightner 1988).

Typical WSSV histopathological features are hypertrophied nuclei with basophilic inclusion bodies in ectodermal and mesodermal tissues such as cuticular epithelial, connective tissue cells, antennal gland epithelium, lymphoid organ and hematopoietic tissues. Their presence was further classified numerically from 0 (no lesions) to 4 (severe tissue damage), as described previously (Lightner 1996).

DNA extraction. DNA was extracted using a modification of the method described by Chomczynski \& Saccin (1987). Briefly, $100 \mu \mathrm{l}$ of haemolymph were added to $400 \mu \mathrm{l}$ lysis buffer (68\% guanidine thiocyanate [Promega] and $120 \mu \mathrm{g} \mathrm{m}^{-1}$ glycogen [ICN Pharmaceutical]) and incubated at room temperature for $10 \mathrm{~min}$. After adding $500 \mu \mathrm{l}$ isopropyl alcohol, samples were centrifuged at $14000 \times g$ for $15 \mathrm{~min}$. Pellets were washed with $1 \mathrm{ml} 70 \%$ ethanol and centrifuged at $14000 \times g$ for $5 \mathrm{~min}$. Each sample was resuspended in $200 \mu \mathrm{l}$ Tris-EDTA buffer. Extracted DNAs were then amplified using shrimp $\beta$-actin primers as described previously (Briñez et al. 2003), to rule out the presence of PCR inhibitors (data not shown).

WSSV quantification. Oligonucleotide forward (5'Tag-ACA-CTA-gTA-gTg-TTA-TTg-CT 3') and reverse (5' TTg-CTT-Tgg-gCC-TCA-TCA-C 3') primers amplify a $69 \mathrm{bp}$ fragment of the WSSV genome (Tang-Nelson \& Lightner 2001). Amplification reactions were carried out in a volume of $20 \mu \mathrm{l}$ using $2 \times$ SYBR Green (DyNAmo Sybr Green qPCR kit, Finnzymes), $1.25 \mu \mathrm{M}$ of each primer, $2 \mathrm{mM} \mathrm{MgCl} \mathrm{Mg}_{2}$ and $2 \mu \mathrm{l}$ of DNA. Samples were subjected to 40 cycles of $10 \mathrm{~s}$ at $95^{\circ} \mathrm{C}$ and $1 \mathrm{~min}$ at $60^{\circ} \mathrm{C}$ in a thermocycler PTC-200/Opticon CDF-3200 (MJ Research).

The number of WSSV rtPCRU per sample was calculated based on the standard curve generated using the WSSV plasmid DNA, kindly provided by Corporation 


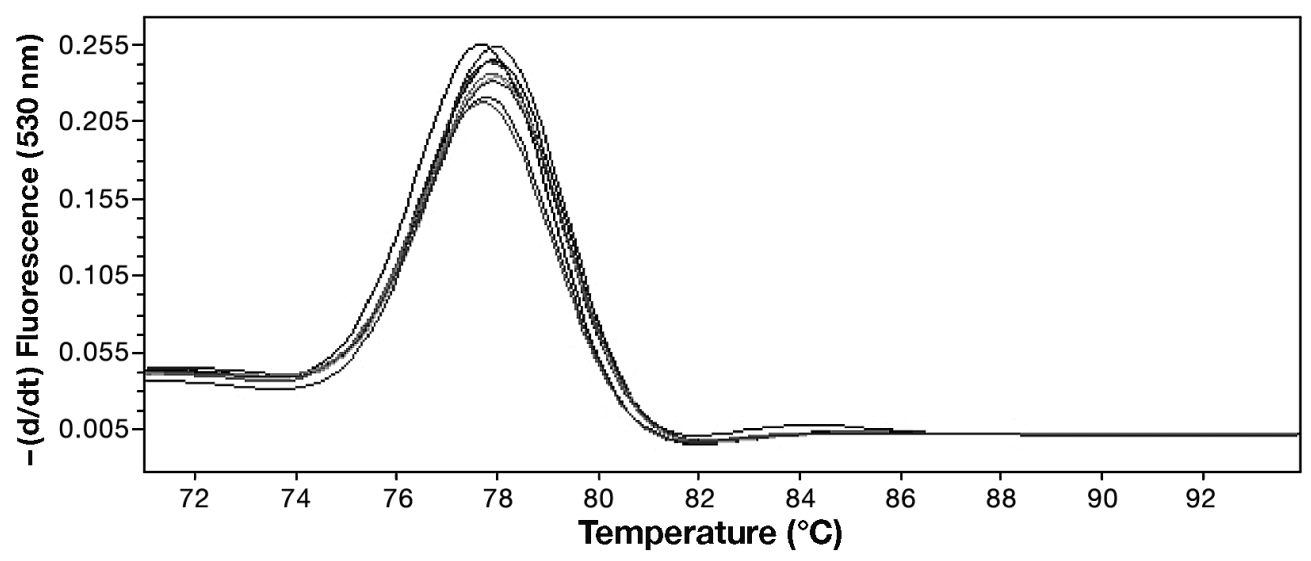

Fig. 1. Penaeus vannamei. Dissociation curves: DNA from 10 WSSV infected $P$. vannamei were amplified with WSSV-specific primers and SYBR Green. The chart plots the first negative derivative of fluorescence for each sample: $-(\mathrm{d} / \mathrm{dt})$

Corpogen. Briefly, an amplified DNA fragment of $1440 \mathrm{bp}$ (Lo et al. 1996) was cloned in the pGEM-T vector. The concentration was determined by spectrophotometry and used to estimate copy numbers. From the stock solution containing $10^{10} \mathrm{rtPCRU}$ of WSSV $\mu l^{-1}$, we prepared serial dilutions to be used as standards in each experiment.

Data analysis. SYBR Green PCR data acquisition and subsequent analysis were performed using Opticon Monitor 1.02 software. This program assigns the threshold cycle (CT) value of each sample, i.e. the cycle at which a statistically significant fluorescence increase was first detected (Dhar et al. 2001). Linear regression analysis and 1-way ANOVA were used for statistical analysis.

\section{RESULTS AND DISCUSSION}

There was no mortality during or immediately after inoculation of the shrimp. By routine histopathology (Lightner 1996) we determined the presence or absence of WSSV in tissues and excluded concomitant diseases. From Group 1 $\left(26^{\circ} \mathrm{C}\right), \quad 29(58 \%)$ shrimp presented typical WSSV nuclear inclusions, which were detected from 18 to $192 \mathrm{~h}$ post-infection. Severe WSSV disease (grades 3-4) occurred in 69\% (20/29) of the cases, mainly after $72 \mathrm{~h}$ postinfection. No WSSV inclusions were found in Group 2 shrimp (maintained at $32^{\circ} \mathrm{C}$ ). As expected, these results showed a significant difference between the groups (Fisher, $\mathrm{p}<0.01$ ) and confirm the effectiveness of the viral inoculum and the absence of
WSSV lesions in shrimp kept at $32^{\circ} \mathrm{C}$ (Vidal et al. 2001, Granja et al. 2003).

To confirm the presence of good quality DNA and the absence of haemolymph PCR-inhibitory factors after guanidine thiocyanate extraction, each sample was PCR amplified with shrimp $\beta$-actin primers. All tested samples gave positive results, validating this DNA extraction protocol for shrimp tissues (data not shown).

As mentioned before, the specificity of real time PCR reaction using SYBR Green is given by the analysis of melting curves (Ririe et al. 1997, Nam et al. 2005). Fig. 1 shows data from 10 of our DNA samples. Their average melting temperature was $78.4 \pm 0.3^{\circ} \mathrm{C}$, matching the Oligo $5^{\circledR}$ prediction of $78.8^{\circ} \mathrm{C}$. Therefore, these results confirm the specific amplification of the WSSV fragment. In addition, the presence of WSSV in the same shrimp was confirmed by conventional nested PCR (Lo et al. 1996) and by histopathology (Lightner 1996).

Based on the inverse correlation between number of WSSV rtPCRU and CT values (Dhar et al. 2001), we

Table 1. Threshold cycle (CT) values of WSSV plasmid standards. CT values correspond to the cycle at which a statistically significant fluorescence increase is first detected. CV: coefficient of variation

\begin{tabular}{|c|c|c|c|c|c|c|}
\hline \multirow[t]{2}{*}{ \# plasmid copies } & \multicolumn{3}{|c|}{ Assay number CT values } & \multirow[t]{2}{*}{ Mean } & \multirow[t]{2}{*}{$\mathrm{SD}$} & \multirow[t]{2}{*}{$\mathrm{CV}$} \\
\hline & 1 & 2 & 3 & & & \\
\hline $1 \times 10^{10}$ & 4.22 & 4.61 & 4.65 & 4.49 & 0.24 & 5.29 \\
\hline $1 \times 10^{8}$ & 9.74 & 10.33 & 9.85 & 9.97 & 0.31 & 3.15 \\
\hline $1 \times 10^{6}$ & 18.59 & 18.74 & 19.24 & 18.86 & 0.34 & 1.80 \\
\hline $1 \times 10^{4}$ & 26.83 & 28.10 & 28.51 & 27.81 & 0.88 & 3.15 \\
\hline $1 \times 10^{2}$ & 32.21 & 32.73 & 33.45 & 32.80 & 0.62 & 1.90 \\
\hline 10 & 33.75 & 33.27 & 34.12 & 33.71 & 0.43 & 1.26 \\
\hline \multicolumn{7}{|l|}{ Controls } \\
\hline WSSV negative DNA & 37.87 & 36.56 & 38.3 & 37.58 & 0.91 & 2.41 \\
\hline Blank (no DNA) & 39.5 & 38.7 & 38.87 & 39.02 & 0.42 & 1.08 \\
\hline Human DNA & None & None & None & 0.00 & 0.00 & 0.00 \\
\hline
\end{tabular}




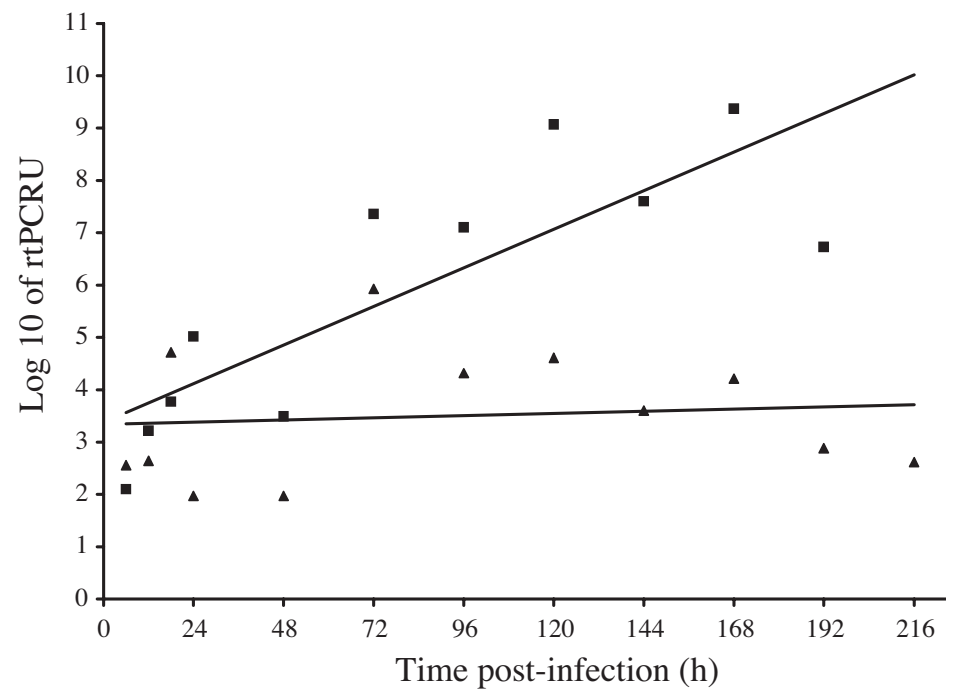

Fig. 2. Linear regression of mean WSSV real time PCR units (rtPCRU), expressed as Logarithm 10: Group $1(\boldsymbol{\nabla}), y=0.645 x+$ 2.0236, $\mathrm{R}^{2}=0.7383$. Group $2(\boldsymbol{\Delta}), y=0.143 x+2.7891, \mathrm{R}^{2}=0.142$

used plasmid dilutions to construct a standard linear regression line for every assay. The rtPCRU of each sample was then calculated by plotting its CT value on this line. These numbers of WSSV units were analyzed after logarithmic transformation. The detection limits of $10^{10}$ to $10^{2} \mathrm{rtPCRU}$ per $100 \mu \mathrm{l}$ of haemolymph were established with plasmid dilutions and DNA controls analyzed in 3 independent assays (Table 1). As expected, these results were highly reproducible, with most of the coefficients of variation smaller than $3.5 \%$.

Plasmid standard linear regressions were also used to determine the efficiency of the PCR reaction. Amplification efficiency of data shown in Fig. 1 was 1.95, as calculated by: efficiency $=10^{(-1 / \text { slope })}$.

Fig. 2 shows the mean rtPCRU obtained from 5 shrimp of each group evaluated at different periods post-infection. Linear regression of WSSV rtPCRU from Group 1 shows a significant increase throughout time postinfection $\left(r^{2}=0.7383 ; p<0.001\right)$. Conversely, there were no rtPCRU differences in Group 2 in any of the evaluated periods $\left(r^{2}=0.142\right)$. In addition, comparison between the groups shows no difference in the WSSV rtPCRU up to $48 \mathrm{~h}$ post-infection (Fig. 3). After $72 \mathrm{~h}$, shrimp from Group 1, maintained at $26^{\circ} \mathrm{C}$, had a significantly higher WSSV rtPCRU (ANOVA, p < 0.001). These findings suggest that hyperthermia produces inappropriate conditions for viral replication.

Indeed, the effect of temperature on WSSV infection has been confirmed in other species. Indirect measurement of WSSV DNA amount by dot blot showed a similar effect of hyperthermia on infected Penaeus japonicus (also called Marsupenaeus japonicus), although the smallest relative viral concentration occurred at $15^{\circ} \mathrm{C}$ (Guan et al. 2003). In another study, there were no mortalities in WSSV infected crayfish at temperatures ranging from 4 to $12^{\circ} \mathrm{C}$, while mortality rapidly reached $100 \%$ in animals kept at $22^{\circ} \mathrm{C}$ (Jiravanichpaisal et al. 2004). As optimal temperature in nature for crayfish is around 15 to $20^{\circ} \mathrm{C}$, these authors suggested that the replication of WSSV was severely affected by low temperatures.

Recent publications have also shown that elevated temperature can have antagonistic effects on viral loads, depending on the experimental model. In larval salamanders Ambystoma tigrinum infected with Ranavirus, a temperature of $26^{\circ} \mathrm{C}$ increases viral replication and, interestingly, survival too (Rojas et al. 2005). Gilad et al. (2004) studied a model of koi herpesvirusinfected Cyprinus carpio koi and found an increase in viral load at high temperatures, while there was no mortality at $13^{\circ} \mathrm{C}$. Furthermore, in mammals, it has been demonstrated that temperature can affect the pathogenicity of HTLV-1 virus by altering the binding of the virions (Hague et al. 2003). In herpes simplex

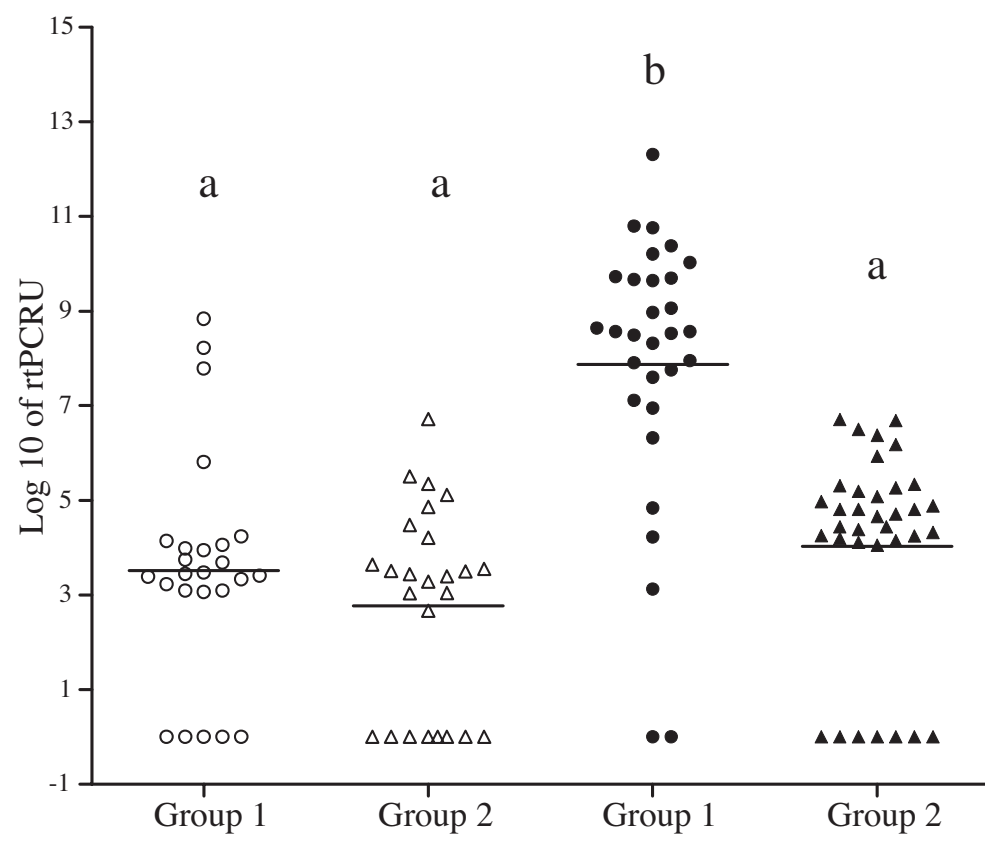

Fig. 3. Vertical scatter plot showing the distribution of WSSV real time PCR units (rtPCRU), presented as Logarithm 10, from all shrimp analyzed. Empty symbols represent time points up to $48 \mathrm{~h}$, filled symbols time points from $72 \mathrm{~h}$ post-infection. Horizontal bar represents the mean values for each group. Different letters represent significant differences (ANOVA, $\mathrm{p}<0.001$ ) 
virus infection, temperature may reduce the envelopment mediated by binding of capsids to cellular organelles (Kamen et al. 2005).

As we have previously shown, this hyperthermia effect in Penaeus vannamei is independent of the route of infection; the same results were obtained using injection and oral doses of WSSV inoculum (Vidal et al. 2001). In addition, this effect does not eliminate the virus, because transferring infected shrimp from 32 to $26^{\circ} \mathrm{C}$ triggered WSSV disease, and mortality occurred within 3 to $4 \mathrm{~d}$ (Vidal et al. 2001). Taken together, our results show that hyperthermia-associated rtPCRU reduction could reflect an increment in the shrimp antiviral response, or its negative effect on the viral replication process, or both. Therefore, additional work concerning the interactions among shrimp, virus and temperature will be required to answer these questions.

Acknowledgements. We thank the Colombian funding agency PNPC and COLCIENCIAS for their support.

\section{LITERATURE CITED}

Anil TM, Shankar KM, Mohan CV (2002) Monoclonal antibodies developed for sensitive detection and comparison of white spot syndrome virus isolates in India. Dis Aquat Org 51:67-75

Bell TA, Lightner DV (1988) A handbook of normal penaeid shrimp histology. Spec Publ, World Aquaculture Society, Baton Rouge, LA

Briñez B, Aranguren F, Salazar M (2003) Fecal samples as DNA source for the diagnosis of necrotizing hepatopancreatitis (NHP) in Penaeus vannamei broodstock. Dis Aquat Org 55:69-72

Chomczynski P, Sacchi N (1987) Single-step method of RNA isolation by acid guanidinium thiocyanate-phenol-chloroform extraction. Anal Biochem 162:156-159

Dhar AK, Roux MM, Klimpel KR (2001) Detection and quantification of infectious hypodermal and hematopoietic necrosis virus and white spot syndrome virus in shrimp using real-time quantitative PCR and SYBR green chemistry. J Clin Microbiol 39:2835-2845

Durand SV, Lightner DV (2002) Quantitative real time PCR for the measurement of white spot syndrome virus in shrimp. J Fish Dis 25:381-389

Durand S, Lightner DV, Nunan LM, Redman RM, Mari J, Bonami JR (1996) Application of gene probes as diagnostic tools for white spot baculovirus (WSBV) of penaeid shrimp. Dis Aquat Org 27:59-66

Gilad O, Yun S, Zagmutt-Vergara FJ, Leutenegger CM, Bercovier H, Hedrick RP (2004) Concentration of a Koi herpesvirus (KHV) in tissues of experimentally infected Cyprinus carpio koi as assessed by real-time TaqMan PCR. Dis Aquat Org 60:179-187

Granja CB, Aranguren LF, Vidal OM, Aragón L, Salazar M (2003) Does hyperthermia increase apoptosis in white spot syndrome virus (WSSV)-infected Litopenaeus vannamei? Dis Aquat Org 54:73-78

Guan Y, Yu Z, Li C (2003) The effects of temperature on white spot syndrome infections in Marsupenaeus japonicus. J Invert Pathol 83:257-260
Hague BF, Zhao TM, Kindt TJ (2003) Binding of HTLV-1 virions to $T$ cells occurs by a temperature and calcium-dependent process and is blocked by certain type 2 adenosine receptor antagonists. Virus Res 93:31-39

Huang J, Ong XL, Yu J, Yang CH (1994) Baculoviral hypodermal and hematopoietic necrosis-pathology of the shrimp explosive epidemic disease. Yellow Sea Fishery Research Institute, Qingdao (Abstract)

Inouye $\mathrm{K}$, Miwa $\mathrm{S}$, Oseko $\mathrm{N}$, Nakano $\mathrm{H}$, Kimura $\mathrm{T}$, Momoyama K, Hiraoka M (1994) Mass mortalities of cultured Kuruma shrimp Penaeus japonicus. Japan in 1993: electron microscopy evidence of a causative virus. Fish Pathol 29:149-158

Jiravanichpaisal P, Söderhäll K, Söderhäll I (2004) Effect of water temperature on the immune response and infectivity pattern of white spot syndrome virus (WSSV) in freshwater crayfish. Fish Shellfish Immunol 17:265-275

Kamen DE, Gross ST, Girvin ME, Wilson DW (2005) Structural basis for the physiological temperature dependence of the association of VP16 with the cytoplasmic tail of herpes simplex virus glycoprotein H. J Virol 79:6134-6141

Lightner DV (1996) A handbook of shrimp pathology and diagnostic procedures for diseases of cultured penaeid shrimp. World Aquaculture Society, Baton Rouge, LA

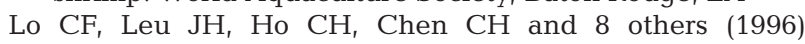
Detection of baculovirus associated with white spot syndrome (WSBV) in penaeid shrimp using polymerase chain reaction. Dis Aquat Org 25:133-141

Magbanua FO, Natividad KT, Migo VP, Alfafara CG and 6 others (2000) White spot syndrome virus (WSSV) in cultured Penaeus monodon in the Philippines. Dis Aquat Org 42:77-82

Nadala ECB, Loh PC (2000) Dot-blot nitrocellulose enzyme immunoassays for the detection of white-spot virus and yellow-head virus of penaeid shrimp. J Virol Methods 84:170-175

Nadala ECB, Tapay LM, Cao S, Loh PC (1997) Detection of yellowhead virus and Chinese baculovirus in penaeid shrimp by the Western blot technique. J Virol Methods 69:39-44

Nam HM, Srinivasan V, Gillespie BE, Murinda SE, Oliver SP (2005) Application of SYBR green real-time PCR assay for specific detection of Salmonella spp. in dairy farm environmental samples. Int J Food Microbiol 102:161-71

Nunan LM, Lightner DV (1997) Development of a nonradioactive gene probe by PCR for detection of a white spot syndrome virus (WSSV). J Virol Methods 63:193-201

Poulos BT, Pantoja CR, Bradley-Dunlop D, Aguilar J, Lightner DV (2001) Development and application of monoclonal antibodies for the detection of white spot syndrome virus of penaeid shrimp. Dis Aquat Org 47:13-23

Ririe KM, Rasmussen RP, Wittner CT (1997) Product differentiation by analysis of DNA melting curves during the polymerase chain reaction. Anal Biochem 245:154-160

Rojas S, Richards K, Jancovich JK, Davidson EW (2005) Influence of temperature on Ranavirus infection in larval salamanders Ambystoma tigrinum. Dis Aquat Org 63: 95-100

Rosenberry B (2002) World shrimp farming. Shrimp News International, San Diego, CA

Tang-Nelson K, Lightner DV (2001) Development of real-time PCR assays for detection of white spot syndrome virus, yellow head virus, Taura syndrome virus, and infectious hypodermal and hematopoietic necrosis virus in penaeid shrimp. Grant Report NA06FD044, available at: www.nmfs.noaa.gov/mb/sk/saltonstallken/whitespot.htm

Tsai JM, Wang HC, Leu JH, Hsiao HH, Wang AHJ, Kou GH, Lo CF (2004) Genomic and proteomic analysis of thirty- 
nine structural proteins of shrimp white spot syndrome virus. J Virol 78:11360-11370

van Hulten MCW, Witteveldt J, Peters S, Kloosterboer N and 5 others (2001) The white spot syndrome virus DNA genome sequence. Virology 286:7-22

Vidal OM, Granja CB, Aranguren F, Brock JA, Salazar M (2001) A profound effect of hyperthermia upon the survival of $L$. vannamei juveniles infected with the WSSV. J World Aquacult Soc 32:364-372

Vlak JM, Bonami JR, Flegel TW, Kou GH, Lightner DV, Lo

Editorial responsibility: Tim Flegel,

Bangkok, Thailand
CF, Loh PC, Walker PW (2004) Nimaviridae. In: Fauquet CM, Mayo MA, Maniloff J, Desselberger U, Ball LA (eds) 8th Report of the International Committee on Taxonomy of Viruses. Elsevier, Amsterdam, p 187-192

Wang SY, Hong C, Lotz JM (1995) Development of a PCR procedure for the detection of a penaeid baculovirus in shrimp. Dis Aquat Org 25:123-131

Yang F, He J, Lin X, Li Q, Pan D, Zhang X, Xu X (2001) Complete genome sequence of the shrimp white spot bacilliform virus. J Virol 75:11811-11820

Submitted: July 14, 2005; Accepted: November 8, 2005

Proofs received from author(s): December 28, 2005 